\title{
Ontogenetic Shifts in Home Range Size of a Top Predatory Reef-associated Fish (Caranx ignobilis): Implications for Conservation.
}

Ryan Daly ( $\square$ ryandaly.mail@gmail.com )

Oceanographic Research Institute https://orcid.org/0000-0002-4409-6951

John David Filmalter

SAIAB

Lauren R Peel

University of Western Australia

Bruce Quinten Mann

Oceanographic Research Institute

James Lea

Save Our Seas Foundation

Christopher R Clarke

Marine Research Facility

Paul D Cowley

South African Institute for Aquatic Biodiversity

\section{Research}

Keywords: Caranx ignobilis, reef-associated fish, Ontogenetic shifts, conservation

Posted Date: October 23rd, 2020

DOI: https://doi.org/10.21203/rs.3.rs-95443/v1

License: (a) (i) This work is licensed under a Creative Commons Attribution 4.0 International License. Read Full License

Version of Record: A version of this preprint was published at Marine Ecology Progress Series on April 15th, 2021. See the published version at https://doi.org/10.3354/meps 13654 . 


\section{Abstract}

Defining the home range of vulnerable species is critical for designing effective spatial management strategies. However, animal home ranges often change with ontogeny and quantifying the associated temporal and spatial changes is particularly challenging for mobile marine species. Here, we investigate how the space use of a top predatory reef-associated fish (Caranx ignobilis) scales with body size. We tagged 17 individuals, representing a wide range of sizes $(40.5-120 \mathrm{~cm}$ fork length $(\mathrm{FL}))$, with acoustic transmitters, and passively tracked them for over 3 years at a tropical island and atoll in the Republic of Seychelles, Western Indian Ocean. We found that a sheltered atoll environment was critical for juvenile fish $(<60 \mathrm{~cm} \mathrm{FL})$ that exhibited a shift in home range location and area as they matured into adults. Small $(60-100 \mathrm{~cm} \mathrm{FL})$ and large ( $>100 \mathrm{~cm} \mathrm{FL}$ ) adult fish appeared to favour shallow coral reefs and associated reef drop offs whilst sharing a similar core home range location. Large adult fish, however, utilized a greater diversity of habitat types and had significantly $(p<0.05)$ greater annual dispersal distances (mean $=35.29 \mathrm{~km}$, $\max =$ $91.32 \mathrm{~km}$ ) than small adults (mean $=13.72 \mathrm{~km}, \max =21.55 \mathrm{~km}$ ). Additionally, the home range (represented by minimum convex polygons) of large adults (mean $\left.=209.74 \mathrm{~km}^{2}\right)$ was significantly $(p<0.05)$ larger than that of juveniles (mean $\left.=38.73 \mathrm{~km}^{2}\right)$ and small adults $\left(77.32 \mathrm{~km}^{2}\right)$ and there was a significant $(p=0.02)$ relationship between fish length and home range size, with fish length accounting for $32 \%$ of the home range size variance. Furthermore, tagged fish took up to 34 months (mean $=18.54$ ) to utilize the full extent of their home range. The habitat shift and expansion in home range size throughout ontogeny exhibited by C. ignobilis in this study should be taken into account when designing effective spatial management plans for the species.

\section{Introduction}

Home range may be defined as the common area an animal repeatedly uses with implications for important ecological processes [1]. As such, defining and protecting a species' home range is critical for the effective design of spatial management initiatives for vulnerable populations [2-4]. The home range of animals, however, is not static, and can change with ontogeny due to shifting demands associated with energetic budgets and reproduction [1]. Typically, there is a linear increase in home range size with increasing body size and mass, which is driven by the need to acquire additional resources to support the increased metabolic requirements of a larger body [5]. The relationship between home range and body size may be further complicated by various factors such as predation risk, diet shifts, habitat shifts, reproduction, and the need to maximise food availability $[6,7]$.

Many fish species undergo substantial ontogenetic change between their larval and adult stages, yet the long term (> 1 year) spatial dynamics of home range shifts throughout these ontogenetic stages remain poorly understood for mobile species because they cannot be observed directly [8]. Given that many large, mobile fishes are also top predators - playing key ecological roles within the various communities that they inhabit - an understanding of their habitat use and movement patterns is significant from both management and ecological perspectives. Such species may facilitate links between ecological processes across various habitats with increasing frequency as they grow and become increasingly mobile $[9,10]$. Understanding the relationship between body size and home range size in reef-associated predatory fish can 
therefore provide important insights into their movement behaviour as well as allow for improved conservation for vulnerable, ecologically and economically important species.

The giant trevally (Caranx ignobilis) is a large and mobile top predatory reef-associated fish species distributed throughout the tropical and sub-tropical Indo-Pacific. Individuals can reach a maximum weight of $80 \mathrm{~kg}$, total length of $1.7 \mathrm{~m} \mathrm{[11]} \mathrm{and} \mathrm{an} \mathrm{age} \mathrm{of} \mathrm{at} \mathrm{least} 25$ years $[12,13]$. Fifty percent maturity is reached after 3-3.5 years, at $60-65 \mathrm{~cm}$ fork length (FL), and they are gonochoristic broadcast spawners that may form aggregations in early summer to spawn [14-16]. Giant trevally are apex predators and are well known to prey on a wide variety of fish species as well as squid and crustaceans $[11,12,17,18]$. Juveniles often settle into nursery areas such as sheltered bays, estuaries or atolls where they remain up to a length of at least 40-55 cm FL [19]. Thereafter, they may move into deeper, reef-associated habitats, however, the drivers of this behavioural and habitat shift remain unclear. It is postulated that this habitat shift may to be related to the onset of sexual maturity and the increased energetic demands of a larger body size [19-22]. Giant trevally are also an iconic fishery species and are prized by recreational anglers worldwide [23]. In the waters of Seychelles, giant trevally are part of the high value catch-and-release fishery, which forms a critical part of the Outer Island tourism sector for the Republic.

The aim of this study was to describe ontogenetic home range scaling in giant trevally. We employed passive acoustic telemetry techniques to investigate the long-term ( $>3$ years) movement behaviour of giant trevally of varying sizes on the Amirante Bank in the Republic of Seychelles, Western Indian Ocean. We hypothesised that dispersal, habitat connectivity and home range size would increase with body size. The findings of this study will aid in developing recommendations for improved conservation of giant trevally.

\section{Methods}

Study site

This study took place at D'Arros Island and St. Joseph Atoll located on the Amirante Bank in the Republic of Seychelles, Western Indian Ocean (Fig. 1). The Amirante Bank is a shallow (typically $<40 \mathrm{~m}$ deep) plateau consisting of 11 low lying sand cay islands with a total land area of $11.5 \mathrm{~km}^{2}$ [24]. D'Arros Island and St. Joseph Atoll make up $3.03 \mathrm{~km}^{2}$ of land and are separated by a channel approximately $900 \mathrm{~m}$ wide and $70 \mathrm{~m}$ deep. The islands contain a diversity of marine habitat types from the atoll lagoon and sand flats to sea grass beds (primarily Thalassodendron ciliatum), to shallow coral reef crests and deeper reef drop-offs, and are home to a diverse fish community [25]. The climate in Seychelles is tropical and dominated by two main seasons. The cooler, drier southwest monsoon season occurs between May and November, and the warmer, wetter northwest monsoon season occurs between December and March [24].

In 2020, the Republic of Seychelles gazetted various new Marine National Parks (Republic of Seychelles Official, Gazette No. 5), including three on the Amirante Bank that were classified as Zone 1 Parks, namely: (1) D'Arros Atoll Marine National Park (Park includes D'Arros Island, but not St. Joseph Atoll); (2) D'Arros to Poivre Atolls Marine National Park; and (3) Amirante South Marine National Park (seen in Fig. 1 in order from north to south, respectively). In total, these Marine National Parks constitute an area of approximately 
$1,732 \mathrm{~km}^{2}$, within which activities such as commercial fishing are regulated (specific regulations yet to be confirmed at time of writing). Additionally, the entire Amirante Bank falls within a designated Area of Outstanding Natural Beauty (Zone 2 Protected Area) within which no commercial fishing by foreign vessels is permitted (regulations yet to be finalized) (Seychelles Official Gazette No. 5).

Habitat types across the study site were classified and mapped using supervised image classification of $2 \mathrm{~m}$ 8 band MS 16-bit orthorectified WorldView-2 high-resolution satellite images from LAND INFO Worldwide Mapping, LLC (Denver, CO, United States), created by $n+p$ biologists (www.nplusp.ch) and copyrighted by the Save Our Seas Foundation. Maps were created in ArcGIS 10.7 (www.esri.com/), Esri, GEBCO, NOAA, National Geographic, DeLorme, HERE, Geonames.org, and other contributors. High resolution imagery of D'Arros and St. Joseph were provided courtesy and Copyright of Drone Adventures for the Save Our Seas Foundation.

\section{Fish tagging and monitoring}

Between the 27th of April and 7th of September 2016, 17 giant trevally were fitted with VEMCO acoustic coded transmitters (Table 1). Fish were captured using standard rod and line tackle and brought onboard a research vessel where they were submerged in a water trough, ventral side up, for the duration of the tagging procedure. Fish less than $60 \mathrm{~cm}$ Fork Length $(\mathrm{FL})$ were surgically implanted with VEMCO V13 $1 \mathrm{~L}$ (nominal delay 120 s, expected battery life 1582 days) acoustic transmitters while larger fish were implanted with VEMCO V16 transmitters (nominal delay 60 s, expected battery life 3650 days). All transmitters were sterilized with surgical sterilant prior to the procedure and were implanted into the peritoneal cavity of each fish through a $2 \mathrm{~cm}$ long incision which was subsequently sutured closed with two independent stiches using a braided silk suture. The incision was then coated with an anti-septic powder forming an adhesive gel prior to the fish's release. The entire capture and tagging procedure typically lasted less than 15 minutes. Tagged fish were monitored using an underwater acoustic receiver array consisting of 89 VEMCO VR2W receivers located throughout the Amirante Bank (Fig. 1).

\section{Fish size classes}

Tagged giant trevally were assigned into three size classes; juveniles $(<60 \mathrm{~cm} \mathrm{FL})$, small adults $(60-100 \mathrm{~cm}$ $\mathrm{FL}$ ) and large adults $(>100 \mathrm{~cm})$. Fish were categorized as small adults based on the length of $50 \%$ sexual maturity determined for the species [12]. Throughout the study period, the growth of tagged individuals was also taken into consideration. The size class of tagged fish was re-assessed on an annual basis and a new size class assigned in accordance with the growth curve derived by Sudekum et al. (1991) (see Supplementary Table 1 for reference). It was assumed that giant trevally in the tropical waters of Seychelles grow at comparable rates to those in the similar tropical Hawaiian marine environment where Sudekum et al. (1991) conducted their growth study, however, further investigation will be required to confirm this assumption. Estimates of fish length post-tagging are therefore used only as a proxy within the present study to compare the relative space use of these fish, and caution should be used when applying our data to populations of giant trevally in different locations. 
For each tagged fish, the number of detections recorded, the number of unique receivers that tagged fish recorded detections on, the total number of days detected and the number of days at liberty (from tagging date to last detection date) was calculated. A residency index was then calculated to examine the percentage of time each tagged individual spent within close proximity to the receiver array throughout the entire study period. This was achieved by dividing the total number of days detected by the number of days at liberty and multiplying by 100 for each fish.

\section{Habitat connectivity}

Network plots were used to visualise the habitat connectivity of the three assigned size classes (juvenile, small adult and large adult) of tagged giant trevally. Plots were constructed in ArcMAP 10.6 (ESRI, Redlands, CA, USA), with nodes representing detection frequency and edges representing join data calculated from receiver detections. Join counts were adjusted per size class to provide standardized and comparable counts. This was done by dividing the total number of detections per size class by the number of individual fish within each size class, and presenting these results as a percentage of the total.

\section{Dispersal distance}

Measures of dispersal distance and activity space were used to investigate the spatial ecology of tagged fish. These metrics were calculated for each tagged giant trevally using functions provided in the 'Animal Tracking Toolbox' extension to the package 'VTrack' [26] in the R statistical environment (version 3.4.1; R Core Team 2017), as described by Udyawer et al. (2018). The "step dispersal" reflected the distances travelled by individuals between subsequent detections in the receiver array, and were calculated using the function 'dispersalSummary'. Step dispersal was calculated for each tagged individual relative to its size class at the time of tagging (i.e. as per Table 1). The dispersal distance between small and large adults were tested for significant difference using a t-test.

\section{Home range size and time to maximum occupancy}

Prior to quantifying home range sizes, short term centres of activity (COAs) that represented the average position of each fish per hour of the study were calculated. The use of COA's accounted for the temporally variable tag transmissions and the spatial biases caused by receiver locations [27]. Home ranges were examined using three activity space metrics: 1 . Total area of occupancy, which was taken to be the full area of calculated Minimum Convex Polygons (MCP's); 2. Core home range area, which was defined as the area in which individuals spent more than $50 \%$ of their time based on Brownian bridge movement models; 3 . The extent of activity space, which was defined as the area in which individuals spent more than $95 \%$ of their time based on Brownian bridge movement models. All home range analyses were conducted using the function "HRSummary" in the package "VTrack" and accounted for the mean detection radius recorded for the receiver array employed in this study (approximately $165 \mathrm{~m}$, Lea et al. 2016). Individual home range plots were then compiled in layers for each size class (juvenile, small adult and large adult) for Fig. 7. A t-test was employed to test for significant differences between all home range results from small and large adults. The rate at which individuals utilized their home range was also investigated. For each individual, the maximum 
occupancy area (represented here by $100 \% \mathrm{MCP}$ ) was calculated on a monthly basis. The time taken for each individual to occupy $100 \%$ of its home range was then calculated and compared among size classes.

\section{Home range size and fish length}

A two-step process was followed to investigate the relationship between home range size and fish length. Firstly, a linear model was used to examine how the maximum occupancy area for the first year of monitoring for each fish varied relative to initial fish length. The significance of fish length in this relationship was assessed using an F-test at an alpha level of 0.05 . Secondly, the maximum area of occupancy, calculated annually for each fish for each year of the study, was compared with both initial (year 1) and predicted (years 2 and 3) fish length as calculated using the growth curve described above. A general linear mixed model (GLMM) that included fish ID as a random effect was used to assess the significance of the relationship in this latter case, and the significance of fish size examined with a chi-squared test through the anova() function. Marginal and conditional $R^{2}$ values were subsequently calculated for the GLMM using the function 'r.squaredGLMM' from the package MuMIn [28] to quantify the proportion of variance explained by fish length alone, and by fish length and fish ID collectively, respectively. These analysis were conducted using the 'Ime4' package in R [29, 30], and, for both models, values of maximum occupancy area were logged prior to analysis to ensure the underlying assumptions of normality were met.

\section{Results}

\section{Tagging}

The 17 tagged giant trevally (four juveniles, eight small adults, five large adults) ranged in size from 40.5 to $120.0 \mathrm{~cm}$ (mean $\pm \mathrm{SD}=82.32 \pm 24.59 \mathrm{~cm})$ and were monitored for between 2 and 1259 days (mean $\pm \mathrm{SD}=$ $759.82 \pm 491.58 \mathrm{~cm}$; Table 1). During this period, individual fish were recorded between 115 and 100430 (mean $\pm S D=12536.82 \pm 23279.10)$ times on 1 to 36 (mean $\pm S D=23 \pm 11$ ) of the 89 acoustic receivers used for the study (Table 1). All of the detections for fish ID 1 ( $40.5 \mathrm{~cm} \mathrm{FL;} \mathrm{Juvenile)} \mathrm{were} \mathrm{recorded}$ consistently on a single receiver suggesting that the fish died after tagging. An additional 2 juvenile fish (ID 2 and 4) were only detected for 3 and 12 days, respectively, and were also presumed to have been lost to post release mortality or predation (Table 1). These three individuals were subsequently removed from any of the proceeding analyses. The residency indices for tagged fish ranged between 46.5 and $93.75 \%$ (mean $\pm \mathrm{SD}=$ $67.82 \pm 13.96 \%$ ) (Table 1). Seven of the 17 tagged fish were detected for more than three years over the study period between 2016 and 2019, whilst five fish were recorded for between one and two years and four fish (three juveniles and one adult) were recorded for less than 1 year (Fig. 2). 
Table 1

Tagging and detection summary for giant trevally fitted with acoustic transmitters.

\begin{tabular}{|c|c|c|c|c|c|c|c|c|}
\hline $\begin{array}{l}\text { Fish } \\
\text { ID }\end{array}$ & $\begin{array}{l}\text { Fork } \\
\text { length } \\
\text { (cm) }\end{array}$ & $\begin{array}{l}\text { Initial } \\
\text { Size } \\
\text { class }\end{array}$ & $\begin{array}{l}\text { Release } \\
\text { date } \\
\text { (d/mo/yr) }\end{array}$ & $\begin{array}{l}\text { No. } \\
\text { detections }\end{array}$ & $\begin{array}{l}\text { No. } \\
\text { unique } \\
\text { receivers }\end{array}$ & $\begin{array}{l}\text { Days } \\
\text { detected }\end{array}$ & $\begin{array}{l}\text { Days } \\
\text { at } \\
\text { liberty }\end{array}$ & $\begin{array}{l}\text { Residency } \\
\text { index (\%) }\end{array}$ \\
\hline $1^{*}$ & 40.5 & Juvenile & 27/04/2016 & 100430 & 1 & 567 & 595 & NA \\
\hline $2^{*}$ & 42.5 & Juvenile & 03/05/2016 & 151 & 5 & 3 & 3 & NA \\
\hline 3 & 45.0 & Juvenile & 04/05/2016 & 9979 & 36 & 425 & 914 & 46.50 \\
\hline $4^{*}$ & 47.0 & Juvenile & 05/05/2016 & 115 & 6 & 12 & 12 & NA \\
\hline 5 & 72.5 & $\begin{array}{l}\text { Small } \\
\text { Adult }\end{array}$ & $05 / 05 / 2016$ & 10282 & 30 & 671 & 1225 & 54.78 \\
\hline 6 & 77.0 & $\begin{array}{l}\text { Small } \\
\text { Adult }\end{array}$ & $07 / 05 / 2016$ & 5356 & 36 & 404 & 707 & 57.14 \\
\hline 7 & 86.0 & $\begin{array}{l}\text { Small } \\
\text { Adult }\end{array}$ & 09/05/2016 & 6012 & 21 & 755 & 1252 & 60.30 \\
\hline 8 & 89.0 & $\begin{array}{l}\text { Small } \\
\text { Adult }\end{array}$ & 09/05/2016 & 3886 & 22 & 370 & 629 & 58.82 \\
\hline 9 & 90.0 & $\begin{array}{l}\text { Small } \\
\text { Adult }\end{array}$ & 09/05/2016 & 21139 & 24 & 817 & 1251 & 65.31 \\
\hline 10 & 92.0 & $\begin{array}{l}\text { Small } \\
\text { Adult }\end{array}$ & 09/05/2016 & 13153 & 27 & 771 & 1259 & 61.24 \\
\hline 11 & 93.0 & $\begin{array}{l}\text { Small } \\
\text { Adult }\end{array}$ & $11 / 05 / 2016$ & 7266 & 29 & 814 & 1246 & 65.33 \\
\hline 12 & 93.0 & $\begin{array}{l}\text { Small } \\
\text { Adult }\end{array}$ & $12 / 05 / 2016$ & 5615 & 29 & 751 & 1227 & 61.21 \\
\hline 13 & 101.0 & $\begin{array}{l}\text { Large } \\
\text { adult }\end{array}$ & $12 / 05 / 2016$ & 130 & 16 & 18 & 25 & 72.00 \\
\hline 14 & 103.0 & $\begin{array}{l}\text { Large } \\
\text { adult }\end{array}$ & $04 / 05 / 2016$ & 9764 & 20 & 280 & 314 & 89.17 \\
\hline 15 & 103.0 & $\begin{array}{l}\text { Large } \\
\text { adult }\end{array}$ & 07/09/2016 & 5579 & 25 & 634 & 797 & 79.55 \\
\hline 16 & 105.0 & $\begin{array}{l}\text { Large } \\
\text { adult }\end{array}$ & 07/09/2016 & 2737 & 22 & 210 & 224 & 93.75 \\
\hline 17 & 120.0 & $\begin{array}{l}\text { Large } \\
\text { adult }\end{array}$ & 14/07/2016 & 11532 & 32 & 1046 & 1239 & 84.42 \\
\hline Mean & 82.32 & & & 12536.82 & 23 & 502.82 & 759.82 & 67.82 \\
\hline SD & 24.59 & & & 23279.10 & 11 & 319.37 & 491.58 & 13.496 \\
\hline
\end{tabular}


Fish were assigned to three size classes based on the measured fork length at the time of capture. Asterisks indicate individuals likely to have suffered post-release mortality.

\section{Habitat connectivity}

Juvenile giant trevally (<60 cm FL) tagged at St. Joseph Atoll ( $n=4)$ exhibited restricted movements away from tagging sites, with the majority of their detections occurring within, and on the margins of, the atoll lagoon environment (Fig. 3). However, considering the short detection period for two of these fish (IDs 2 and 4) and the mortality of a third individual (ID 1), movements of this size class are largely representative of a single fish (ID 3). Nevertheless, substantial data (9,979 detections over 425 days) were recorded for this individual, which showed limited movements within the atoll lagoon during the first year of monitoring. When detected within the bounds of St. Joseph Atoll, this fish made extensive use of the atoll lagoon and, to a lesser extent, the sand flats and sea grass habitats. One hundred and fifty days after tagging, this individual was recorded on one receiver approximately $13 \mathrm{~km}$ to the south west on the shallow Amirante Bank (Fig. 3), where it was detected on 17 occasions over a period of 12 days. Following this excursion, the fish returned to the confines of the atoll.

Small adult fish (60-100 cm FL) were detected around D'Arros Island and the north-western boundary of St. Joseph Atoll, with the highest occurrence recorded on the eastern side of D'Arros Island in the channel opposite St. Joseph Atoll, as well as along the northern edge of the Atoll (Fig. 4). These fish primarily used the shallow coral reef crest and reef drop off habitats of the island and atoll margins. They occasionally used the atoll sand flats but were never detected within the atoll lagoon (Fig. 4). Furthermore, they appeared to undertake occasional movements across the broader Amirante Bank within $31 \mathrm{~km}$ of D'Arros Island and

St. Joseph Atoll (Fig. 4). Fish tagged at D'Arros Island were detected at St. Joseph Atoll and visa versa, highlighting the connectivity between these islands across a deep (70 m) channel spanning a $1 \mathrm{~km}$ gap between D’Arros Island and St. Joseph Atoll.

Similar to the small adult fish, the large adult giant trevally (> $100 \mathrm{~cm} \mathrm{FL)} \mathrm{were} \mathrm{detected} \mathrm{in} \mathrm{habitats}$ associated with D'Arros Island and the north-western boundary of St. Joseph Atoll, with the highest number of detections recorded on the eastern side of D'Arros Island in the channel opposite St. Joseph Atoll (Fig. 5). Large adults were mostly recorded at the coral reef crest and reef drop off habitats on the island and atoll margins, but also used the atoll sand flats, sea grass and lagoon habitats. Furthermore, these individuals made greater use of the broader Amirante Bank than the smaller adult fish, travelling to almost all of the outer islands on the Bank and covering distances of up to $88 \mathrm{~km}$ from the tagging location (Fig. 5). Notably, no movements were recorded at the nearby Desroches Island, approximately $40 \mathrm{~km}$ away, which is separated from the Amirantes Bank by a oceanic trench more than $1000 \mathrm{~m}$ deep (Fig. 1).

\section{Dispersal distance}

The annual dispersal step distance of each fish categorized by size class ranged between 4.78 and $91.32 \mathrm{~km}$ (Fig. 6, Table 2). The only juvenile fish that recorded a full year of data (ID 3) exhibited a maximum step dispersal of $17.35 \mathrm{~km}$ during the first year of monitoring before it transitioned into the small adult size class (60-100 cm FL) in its second year. The mean small adult step dispersal distance was 13.72 (SD = 
5.34) which was significantly less $(p<0.05)$ than the mean step dispersal distance of $35.29(S D=31.18)$ of the large adult size class (Table 2). Many small adult fish that transitioned into large adults during the study period exhibited an increase in the step dispersal distance with length (see ID 9 and 10), although this was not always the case (see ID 12; Table 2).

\section{Home range size}

The annual core home range size of tagged fish, calculated using the $50 \%$ Brownian bridge kernel utilization density, ranged between $0.44 \mathrm{~km}^{2}$ and $9 \mathrm{~km}^{2}$ with mean core home range size of $2.35 \mathrm{~km}^{2}$ for juveniles, $4.06 \mathrm{~km}^{2}$ for small adults and $3.58 \mathrm{~km}^{2}$ for large adults (Table 2). The annual activity space of tagged fish, calculated using the $95 \%$ Brownian bridge kernel utilization density, ranged between $1.36 \mathrm{~km}^{2}$ and $255.89 \mathrm{~km}^{2}$. The mean annual activity space calculated for each size class was $41.37 \mathrm{~km}^{2}, 72.65 \mathrm{~km}^{2}$ and $92.24 \mathrm{~km}^{2}$ for juveniles, small adults, and large adults respectively (Table 2). The annual home range of tagged fish represented by their occupancy area (MCP) ranged between $26.18 \mathrm{~km}^{2}$ and $678.71 \mathrm{~km}^{2}$ with a mean occupancy area of $38.73 \mathrm{~km}^{2}$ for juveniles, $77.32 \mathrm{~km}^{2}$ for small adults and $209.74 \mathrm{~km}^{2}$ for large adults. There was no significant difference in the annual core home range or activity space between small and large adult fish $(p>0.05)$, however, large adults had a significantly $(p<0.05)$ larger annual occupancy area. 
Table 2

Annual dispersal distance and home range metrics for tagged giant trevally.

\begin{tabular}{|c|c|c|c|c|c|c|c|}
\hline $\begin{array}{l}\text { Fish } \\
\text { ID }\end{array}$ & $\begin{array}{l}\text { Obs. } \\
\text { Year }\end{array}$ & $\begin{array}{l}\text { Fork } \\
\text { length } \\
\text { (cm FL) }\end{array}$ & $\begin{array}{l}\text { Size } \\
\text { Class }\end{array}$ & $\begin{array}{l}\text { Dispersal } \\
\text { Max } \\
(\mathrm{km})\end{array}$ & $\begin{array}{l}\text { bbKUD }\left(\mathrm{km}^{2}\right) \\
\text { Core Range }\end{array}$ & $\begin{array}{l}\text { bbKUD } \\
\left(\mathrm{km}^{2}\right) \\
\text { Activity } \\
\text { Space }\end{array}$ & $\begin{array}{l}\text { Occupancy Area } \\
(\mathrm{MCP})\left(\mathrm{km}^{2}\right)\end{array}$ \\
\hline 3 & 1 & 45.0 & Juvenile & 17.35 & 2.35 & 49.37 & 38.73 \\
\hline 3 & 2 & 61.10 & $\begin{array}{l}\text { Small } \\
\text { Adult }\end{array}$ & 18.09 & 2.61 & 33.97 & 93.66 \\
\hline 5 & 1 & 72.50 & $\begin{array}{l}\text { Small } \\
\text { Adult }\end{array}$ & 14.22 & 2.37 & 84.74 & 82.61 \\
\hline 5 & 2 & 85.71 & $\begin{array}{l}\text { Small } \\
\text { Adult }\end{array}$ & 10.67 & 6.37 & 95.67 & 77.34 \\
\hline 5 & 3 & 97.54 & $\begin{array}{l}\text { Small } \\
\text { Adult }\end{array}$ & 8.82 & 3.61 & 73.18 & 70.00 \\
\hline 6 & 1 & 77.00 & $\begin{array}{l}\text { Small } \\
\text { Adult }\end{array}$ & 16.05 & 6.33 & 82.99 & 125.71 \\
\hline 6 & 2 & 89.74 & $\begin{array}{l}\text { Small } \\
\text { Adult }\end{array}$ & 8.95 & 4.61 & 51.41 & 60.78 \\
\hline 7 & 1 & 86.00 & $\begin{array}{l}\text { Small } \\
\text { Adult }\end{array}$ & 21.55 & 3.34 & 79.99 & 65.17 \\
\hline 7 & 2 & 97.79 & $\begin{array}{l}\text { Small } \\
\text { Adult }\end{array}$ & 20.77 & 5.54 & 138.81 & 55.73 \\
\hline 7 & 3 & 108.35 & $\begin{array}{l}\text { Large } \\
\text { Adult }\end{array}$ & 31.19 & 3.13 & 89.60 & 83.52 \\
\hline 8 & 1 & 89.00 & $\begin{array}{l}\text { Small } \\
\text { Adult }\end{array}$ & 7.30 & 3.80 & 50.32 & 53.69 \\
\hline 8 & 2 & 100.48 & $\begin{array}{l}\text { Large } \\
\text { Adult }\end{array}$ & 6.27 & 5.31 & 37.55 & 27.75 \\
\hline 9 & 1 & 90.00 & $\begin{array}{l}\text { Small } \\
\text { Adult }\end{array}$ & 19.93 & 3.19 & 74.34 & 106.06 \\
\hline 9 & 2 & 101.37 & $\begin{array}{l}\text { Large } \\
\text { Adult }\end{array}$ & 12.23 & 3.45 & 110.16 & 58.90 \\
\hline 9 & 3 & 111.55 & $\begin{array}{l}\text { Large } \\
\text { Adult }\end{array}$ & 60.24 & 9.00 & 255.89 & 327.08 \\
\hline 10 & 1 & 92.00 & $\begin{array}{l}\text { Small } \\
\text { Adult }\end{array}$ & 8.84 & 4.42 & 80.02 & 63.82 \\
\hline 10 & 2 & 103.16 & $\begin{array}{l}\text { Large } \\
\text { Adult }\end{array}$ & 10.00 & 8.63 & 171.67 & 53.48 \\
\hline
\end{tabular}




\begin{tabular}{|c|c|c|c|c|c|c|c|}
\hline $\begin{array}{l}\text { Fish } \\
\text { ID }\end{array}$ & $\begin{array}{l}\text { Obs. } \\
\text { Year }\end{array}$ & $\begin{array}{l}\text { Fork } \\
\text { length } \\
\text { (cm FL) }\end{array}$ & $\begin{array}{l}\text { Size } \\
\text { Class }\end{array}$ & $\begin{array}{l}\text { Dispersal } \\
\text { Max } \\
(\mathrm{km})\end{array}$ & $\begin{array}{l}\text { bbKUD }\left(\mathrm{km}^{2}\right) \\
\text { Core Range }\end{array}$ & $\begin{array}{l}\text { bbKUD } \\
\left(\mathrm{km}^{2}\right) \\
\text { Activity } \\
\text { Space }\end{array}$ & $\begin{array}{l}\text { Occupancy Area } \\
(\mathrm{MCP})\left(\mathrm{km}^{2}\right)\end{array}$ \\
\hline 10 & 3 & 113.16 & $\begin{array}{l}\text { Large } \\
\text { Adult }\end{array}$ & 22.94 & 8.32 & 229.03 & 101.56 \\
\hline 11 & 1 & 930 & $\begin{array}{l}\text { Large } \\
\text { Adult }\end{array}$ & 25.15 & 1.92 & 71.92 & 162.58 \\
\hline 11 & 2 & 1040.6 & $\begin{array}{l}\text { Large } \\
\text { Adult }\end{array}$ & 52.71 & 3.77 & 114.36 & 224.70 \\
\hline 11 & 3 & 1139.57 & $\begin{array}{l}\text { Large } \\
\text { Adult }\end{array}$ & 19.90 & 6.13 & 94.36 & 112.14 \\
\hline 12 & 1 & 93.00 & $\begin{array}{l}\text { Small } \\
\text { Adult }\end{array}$ & 9.47 & 2.53 & 26.33 & 73.27 \\
\hline 12 & 2 & 104.06 & $\begin{array}{l}\text { Large } \\
\text { Adult }\end{array}$ & 9.55 & 3.01 & 36.40 & 69.78 \\
\hline 12 & 3 & 113.96 & $\begin{array}{l}\text { Large } \\
\text { Adult }\end{array}$ & 7.70 & 2.17 & 25.72 & 48.52 \\
\hline 13 & 1 & 101.00 & $\begin{array}{l}\text { Large } \\
\text { Adult }\end{array}$ & 84.47 & 2.89 & 210.02 & 654.13 \\
\hline 14 & 1 & 103.00 & $\begin{array}{l}\text { Large } \\
\text { Adult }\end{array}$ & 20.14 & 1.26 & 55.57 & 114.66 \\
\hline 15 & 1 & 103.00 & $\begin{array}{l}\text { Large } \\
\text { Adult }\end{array}$ & 19.64 & 2.76 & 38.86 & 114.16 \\
\hline 15 & 2 & 113.09 & $\begin{array}{l}\text { Large } \\
\text { Adult }\end{array}$ & 33.35 & 2.89 & 78.53 & 77.69 \\
\hline 15 & 3 & 121.97 & $\begin{array}{l}\text { Large } \\
\text { Adult }\end{array}$ & 4.78 & 0.44 & 3.97 & 26.18 \\
\hline 16 & 1 & 105.00 & $\begin{array}{l}\text { Large } \\
\text { Adult }\end{array}$ & 12.85 & 2.08 & 16.16 & 88.02 \\
\hline 17 & 1 & 120.00 & $\begin{array}{l}\text { Large } \\
\text { Adult }\end{array}$ & 91.08 & 1.13 & 41.25 & 520.53 \\
\hline 17 & 2 & 128.22 & $\begin{array}{l}\text { Large } \\
\text { Adult }\end{array}$ & 91.32 & 2.25 & 217.23 & 678.71 \\
\hline 17 & 3 & 135.58 & $\begin{array}{l}\text { Large } \\
\text { Adult }\end{array}$ & 90.24 & 1.13 & 26.56 & 650.68 \\
\hline \multicolumn{3}{|c|}{ Juvenile Mean } & & 17.35 & 2.35 & 49.37 & 38.73 \\
\hline \multicolumn{3}{|c|}{ Small adult Mean (SD) } & & $13.72(5.34$ & $4.06(1$ & $\begin{array}{l}72.65 \\
(29.94)\end{array}$ & $77.32(21.65)$ \\
\hline
\end{tabular}




\begin{tabular}{|lllllll|}
\hline $\begin{array}{l}\text { Fish } \\
\text { ID Obs. }\end{array}$ & $\begin{array}{l}\text { Fork } \\
\text { length } \\
(\mathrm{cm} F \mathrm{FL})\end{array}$ & $\begin{array}{l}\text { Size } \\
\text { Class }\end{array}$ & $\begin{array}{l}\text { Dispersal } \\
\text { Yax } \\
(\mathrm{km})\end{array}$ & $\begin{array}{l}\text { bbKUD }\left(\mathrm{km}^{2}\right) \\
\text { Core Range }\end{array}$ & $\begin{array}{l}\text { bbKUD } \\
\left(\mathrm{km}^{2}\right) \\
\text { Activity } \\
\text { Space }\end{array}$ & $\begin{array}{l}\text { Occupancy Area } \\
(\mathrm{MCP})\left(\mathrm{km}^{2}\right)\end{array}$ \\
\hline Large Adult Mean (SD) & & $35.29(31.18)$ & $3.58(2.57)$ & $\begin{array}{l}96.24 \\
(78.68)\end{array}$ & $\begin{array}{l}209.74 \\
(226.16)\end{array}$ \\
\hline Minimum & & 4.78 & 0.44 & 1.36 & 26.18 \\
\hline Maximum & & 91.32 & 9.00 & 255.89 & 678.71 \\
\hline
\end{tabular}

Note that a growth curve was used to assign tagged fish an annual size class (see Supplementary Material 1). Core home range ( $50 \%$ contour) and activity spaces ( $95 \%$ contour) were calculated using Brownian bridge kernel utilization densities (bbKUD). Occupancy area (representative home range) was calculated using Minimum Convex Polygons (MCP's). No home range metrics were calculated for fish that were at liberty for less than 30 days.

\section{Home range size and fish length}

The results of the linear model indicated a significant positive relationship $\left(F_{1,13}=7.84, p=0.02\right)$ between the log-transformed maximum occupancy area (represented by the $100 \%$ Minimum Convex Polygon area) and fish length during the first year of monitoring (Fig. 8A), with fish length explaining $32.8 \%$ of the variation in the data. The linear mixed model revealed a similar significant relationship between fish length and logged maximum occupancy area $\left(X^{2}=4.25, d f=1, p=0.04\right.$; Fig. $8 B$ ) when compared to the null model. Fish length explained $13.04 \%$ of the variation in the data (marginal $R^{2}=0.13$ ), whereas the combination of fish length and fish ID $(n=14)$ explained $0.70 \%$ (conditional $\left.R^{2}=0.70\right)$.

\section{Time to maximum occupancy}

The time it took tagged fish to reach the maximum total area of occupancy, represented by the Minimum Convex Polygon (MCP) area $\left(\mathrm{km}^{2}\right)$ ranged between 7 and 34 months (Mean $=18.5$ months) (Fig. 9). This suggests that area use increases gradually as tagged fish took at least one and a half years to use the complete extent of their home range.

\section{Discussion}

When investigating spatial protection for fish and their associated habitats, many studies have considered home range size and egg and larval dispersal of the species concerned (inter alia [31, 32]). However, few studies have considered the implications of changes in home range size that occur with ontogeny, especially for more mobile species. In this study we show that for giant trevally (Caranx ignobilis), a top reef predator and an iconic fishery species, habitat connectivity, dispersal distance and home range size increases significantly with fish size. Additionally, the type of habitat used by adults differs fundamentally from the more sheltered nursery habitats used by juveniles. This has important implications for spatial management of the species and the habitats that it frequents. 


\section{Detection summary}

Seven out of the 17 tagged fish in this study were monitored for the full period of this study (3.5 years) representing some of the longest tracked and monitored giant trevally on record $[10,16,33]$. Additionally, tagged fish ranged in size from 45 to $135 \mathrm{~cm}$ (calculated size) representing the largest range in size of tracked fish as well as some of the largest giant trevally tracked on record [33, 34]. The overall detection frequency and residency index of tagged fish within the receiver array at the study site was relatively high (mean $=67.82$ ) and similar to previous studies $[10,34]$ suggesting that the receiver array at the study site provided good coverage of the movements of this species (Fig. 2, Table 1).

\section{Habitat connectivity}

Although we had a limited sample size of juveniles to thoroughly investigate the habitat use of this life stage, evidence from this study appears to support previous research, highlighting the importance of sheltered habitats for juveniles before they disperse and move between habitats over broader spatial scales when reaching approximately $50-60 \mathrm{~cm}$ in fork length $[19,20]$. Sheltered bays, lagoons and estuaries often form a critical nursery environment for juvenile fishes as these habitats provide shelter, food and relatively low predation risk [35]. Indeed, the sheltered habitat provided by the St. Joseph Atoll lagoon may play a key role for many fish species that exhibit ontogenetic migrations between a sheltered nursery habitats to more exposed coral reef dominated ecosystems [36]. Such nursery habitats can play a critical role in the structure, diversity and biomass of associated fish communities and it appears that St. Joseph Atoll may be particularly important for giant trevally recruitment as it is one of only a few sheltered habitats within the broader region $[37,38]$.

The transition from juvenile to adult habitat use in giant trevally appeared to be characterized by a substantial shift in habitat type from an atoll lagoon to a coral reef environment. Many species undertake ontogenetic migrations and transition out of one habitat to another as their requirements for shelter, food and reproduction change $[1,5,7,39]$. Indeed, the distinct change in habitat use recorded between juvenile and adult phases in this study suggests the occurrence of a shift in the functional phase of the fish. This is supported by the fact that there was a 4 to 5 fold increase in home range size (as measured by the core range, activity space and occupancy area) from the juvenile to small adult phase which coincided with the use of new habitat types (Table 2, Fig. 4). Such a rapid increase in the area occupied by fish and associated habitat shift may be linked to attaining a size threshold where predation risk decreases substantially $[8,40]$. As giant trevally grow into adults they would have less risk of predation from the many top predatory sharks present at the study site known to prey on small reef fish including juvenile giant trevally [41-43]. Such a release of predation risk is probably an important factor determining the timing of the transition between juvenile and adult habitat for giant trevally $[40,44]$. Additionally, the transition from the juvenile habitat to adult habitat occurs close to the size at sexual maturity $(60 \mathrm{~cm})$ and it is likely that reproduction is also a key driver of this shift. Such an ontogenetic step change in area use and habitat type, as observed in this study, is indicative of shift into maturity driven by reproductive demands [8].

Large adults appeared to connect a wider diversity of habitat types from shallow reefs, atoll sand flats and lagoons to broad ranging excursions throughout the Amirante Bank (Fig. 5). Both small and large adults 
appeared to share a common central area of use with similar core habitat types with a diverse and productive marginal coral reef around D'Arros and St. Joseph as well as the deep channel between these islands which has been observed to be an especially productive feature utilized by other large reef fish at the study site $[24,25,45]$. Thus, it appears that this core area meets the trophic demands of all small adult fish, but potentially not the large adult fish which range throughout the Amirante Bank [18]. By the end of the monitroing period the largest adult fish would have weighed in excess of $40 \mathrm{kgs}$ (maximum size fish ID 17 was calculated to measure $135.5 \mathrm{~cm}$ or $48 \mathrm{~kg}$ in year 3) and as such, represented a large-bodied top predator with substantial dietary demands. To fullfil their energetic requirements, these large adult fish likely need to range further than smaller adults to locate sufficient feeding opportunities. Similar wide ranging movements driven by foraging are observed in many other species and often occur as these animals need to increase their prey encounter rates $[1,46]$.

\section{Dispersal distance}

The maximum annual step dispersal distance recorded by a juvenile giant trevally (ID 3) appeared to be representative of the single foray out of St. Joseph Atoll (Fig. 3). This excursion was likely the start of the fish's transition to an adult environment as the fish attained over $60 \mathrm{~cm}$ FL within the first year of monitoring. Unfortunately, due to post release mortality, the annual maximum dispersal distances of the other juvenile fish tagged in this study could not be determined but observations confirmed that juveniles are likely confined to the atoll lagoon habitat. The observed significantly $(p<0.05)$ greater annual mean step dispersal distances exhibited by large adults was most likely driven by foraging demands as discussed previously. Interestingly, for those small adult fish that were tracked over multiple years, some fish increased their maximum dispersal substantially as they grew (fish ID 9 and 10) whilst some others appeared to maintain relatively similar maximum dispersal distances over the monitoring period (fish ID 12). This may reflect some individual differences in habitat use. For fish ID 17, the recorded annual maximum step dispersal distance remained constant (year $1=91.08$, year $2=91.32$, year $3=90.24$ ) highlighting the mobility of this large adult fish and it suggests that the extent of the receiver array may not have been large enough to capture this fish's true maximum dispersal distances. Indeed, giant trevally have been tracked undertaking return migrations to and from spawning aggregations of over $1200 \mathrm{~km}$ emphasizing the remarkable dispersal capabilities of this species [16]. However, tagged fish remained on the Amirante Bank and did not cross the deep channel (oceanic trench) separating the bank from Desroches Island, approximately $40 \mathrm{~km}$ away. Hence, it is possible that the maximum dispersal distance is restricted to the extent of the Amirante Bank and that dispersal is limited by deep water (>1000 m) as fish may not cross deep open ocean. It is however possible that early life history stages (eggs and larvae) are transported between the bank and other other island because evidence from genomic work indicate a panmitic population throughout the southwest Indian Ocean (JR Glass, pers comm).

\section{Home range}

The overall annual core home range $\left(0.44-9.31 \mathrm{~km}^{2}\right)$ and activity space $\left(1.36-255.89 \mathrm{~km}^{2}\right)$ calculated in this study was orders of magnitude greater than the monthly core range $\left(0.0001-0.016 \mathrm{~km}^{2}\right)$ and activity space (0.004-0.062 $\mathrm{km}^{2}$ ) of giant trevally monitored at a coral reef in Australia [34]. Although, this may 
simply reflect the different time scales (annual vs monthly) and the different spatial extent of the respective receiver arrays. However, giant trevally in both studies did appear to exhibit a persistent core area of habitat use representing a key habitat and site attachment. The size of the core range and activity space between small adult and large adult was not significantly different $(p>0.05)$, however, there was a significant $(p<$ $0.05)$ increase in the maximum occupancy areas between small $\left(92.74 \mathrm{~km}^{2}\right)$ and large $\left(207.57 \mathrm{~km}^{2}\right)$ adult fish. The similar core ranges of small and large adult fish most likely represent an overlapping key habitat whilst the increase in maximum occupancy areas between small and large adults appears to be driven by the increased dispersal distance undertaken by large adults.

In comparison to many other coral reef-associated teleosts, the home range size calculated for giant trevally in this study (represented by the total occupancy area, Table 2) was substantially larger [47] (see supplimentary Table S1 therein). In fact, the total occupancy area of large adult giant trevally was more similar to and or greater than several large bodied shark species (Negaprion acutidens, Carcharhinus melanopterus and Carcharhinus amblyrhyncos) monitored at the same study site [42]. This highlights the ecological role played by adult giant trevally as a top predator linking ecological processes over large spatial scales. Indeed, the trophic position of giant trevally was recently found to be equivalent to many top predatory shark species confirming its role as an apex predator within their respective marine communities [18].

\section{Home range scaling}

As animals requirements for resources increase with body size, an increase in home range size typically occurs [1]. However, this relationship is complicated by predation risks and reproductive demands. For some reef fish, the social status linked to reproduction limits the home range of mature adults and breaks down the relationship between fish size and home range area $[8,45]$. However, giant trevally do not have such reproductively driven social and territorial constraints, other than the need to aggregate annually to spawn. Previously, giant trevally have been recorded travelling over $1200 \mathrm{~km}$ between annual spawning aggregation events [16]. Therefore, the observed relationship between fish length and home range area (Fig. 8) is likely driven by foraging events as the metabolic demands of larger fish increase with size and they range further in search of prey [18]. However, fish size only explained $33 \%$ of the home range size variance in the linear model, suggesting that other factors are also important determinants of home range size for this species. Besides the step change in home range location and size from juveniles to adults, likely driven by reduced predation risk and maturation, individual foraging strategies and learned behaviour may also play an important role determining the home range of these fish. Results from the linear mixed model also revealed a strong influence of individual ID (57\% deviance explained) on reported maximum occupancy area in comparison to the effect of fish size ( $13 \%$ deviance explained). This is likely due to the relatively small cohort of tagged fishes available in this study, the tagging bias towards small and large adults (due largely to post-release mortality occurring in juveniles) and a reliance on original length measurements to estimate future fish growth and sizes throughout the monitoring period. In order to further refine the current understanding of spatio-temporal home range scaling in giant trevally relative to size, future studies should aim to increase the number of tagged fishes and ensure an even distribution of tags across ontogenetic stages throughout the entire monitoring period. 


\section{Time to maximum occupancy}

The time it took individual fish to reach their total area of occupancy varied between 7 and 34 months suggesting that individual fish may expand their home range size over variable and long periods of time (Fig. 9). For example, large adult fish ID 12 rapidly (6 moths) utilized its total area of occupancy whilst large adult fish ID 10 took 28 months to utilize its total area of occupancy. Although both these fish were large adults, presumably with similar metabolic requirements, it suggests that individuals may adopt new foraging strategies based on learned behaviour or changing prey availability over time [48]. Further research is required to better understand how important learned behavior and individual foraging strategies are in determining fish habitat use and home range size. Nevertheless, this study confirmed that the maximum extent of a fish's home range size may only be recorded after long periods (at least 18 to 34 months). This highlights the need to carefully consider the duration of the monitoring period and the spatial extent of receiver arrays for acoustic telemetry studies that aim to define the full extent of space use and home ranges of mobile aquatic species.

\section{Implications for conservation}

This study highlighted the importance of sheltered habitat within the St. Joseph Atoll as a nursery area for giant trevally in the region and confirmed that the juvenile and small adult core areas of habitat were spatially separate. The sheltered habitat of St. Joseph Atoll likely plays a critical role in recruitment success

of giant trevally, as well as many other nursery dependent reef fish species and should thus be prioritised for conservation [37, 38]. For example, the protection of St. Joseph Atoll lagoon, reef flats and associated coral reef crests and drop offs will also protect critical habitat for Endangered humphead wrasse and other vulnerable species that frequent this unique habitat $[41,42,45]$. However, as highlighted in this study, prioritising the protection of St. Joseph Atoll should be done together with the surrounding marine environment to promote ecological processes and facilitate demographic and geographic linkages $[9,31]$. This study has shown that giant trevally are capable of wider ranging movements than previously reported $[33,34,49,50]$ and to effectively protect the core range and activity space of adults, a protected area of at least $72.65 \mathrm{~km}^{2}$ of suitable habitat would be required. Additionally, to account for the dispersal distances and total area of occupancy of large adults, such a protected area would need to encompass at least $168.36 \mathrm{~km}^{2}$, but up to $678.71 \mathrm{~km}^{2}$, representing the maximum recorded occupancy area of a tagged large adult giant trevally. Protecting such vast areas represents significant challenges for management and enforcement but the information garnered in this study can be used to help prioritise effective conservation measures [51]. The newly proclaimed Marine National Parks in Seychelles are a positive step towards large protected areas which may incorporate large portions of habitat of wide ranging species (Fig. 1, Seychelles Official Gazette No. 5). Additionally, we recommend that St. Joseph is prioritised for conservation with a ban on consumptive fishing and that further research is conducted into identifying the potential spawning aggregation sites within the recorded activity space of tagged adult fish. In order to maximise the effectiveness of such a protected area, we suggest expanding it from St. Joseph Atoll to include the associated habitat of co-occuring endangered and vulnarable species to encompass an area of at least $72.65 \mathrm{~km}^{2}$ around St. Joseph Atoll. 


\section{Summary}

This study has confirmed that giant trevally exhibit an increase in space use area with increasing body size supporting our primary hypothesis. An important driver of a shift in home range location and area / habitat type from the juvenile to adult phase appeared to be a release in predation risk and a shift to sexual maturity. The core activity space of small adult and large adult fish was largely similar but the maximum dispersal distance and occupancy area of large adult fish was substantially greater than that of small adult fish, probably driven by foraging excursions as the metabolic needs of such large fish increase. The study also found that the home range of giant trevally at a tropical island and atoll marine ecosystem was larger than previously reported [33] and that individually tracked fish took long periods of time (mean = 18.54 months) to utilise the full extent of their activity space. These findings indicate that in order to effectively conserve this iconic and ecologically important top predatory fish, the conservation of sheltered nursery areas should be prioritised and that the extent of small and large adult home ranges and dispersal distances need to be taken into consideration.

\section{Declarations}

\section{Ethics approval}

This study was conducted with permission from the NRF SAIAB Animal Ethics Committee.

\section{Consent for publication}

All authors consent to the publication of this study.

\section{Availability of data and material}

The data used in this study is archived in an electronic database with the Save Our Seas D'Arros Research Centre.

\section{Competing interests}

There are no competing interests.

\section{Funding}

This study was funded by a Save Our Seas Foundation Keystone Grant (\#312). Additional support was provided by the National Research Foundation and the South African Institute for Aquatic Biodiversity through a grant administered by PDC.

\section{Authors contributions}

RD, JDF and PC conducted field work and wrote the manuscript. LRP conducted data analysis and contributed to the writing on the MS. JSEL and CRC supported and conducted field work and contributed to the writing of the MS. BQM contributed to the writing of the MS. 
We acknowledge the logistical support provided by staff of the D'Arros Research Centre. We thank the Seychelles Bureau of Standards and the Seychelles Ministry of Environment, Energy and Climate Change for their support.

\section{References}

1. Börger $L$, Dalziel BD, Fryxell JM. Are there general mechanisms of animal home range behaviour? A review and prospects for future research. Ecol Lett. 2008;11:637-50.

2. Kramer DL, Chapman MR. Implications of fish home range size and relocation for marine reserve function. Environ Biol Fishes. Springer Netherlands; 1999;55:65-79.

3. Moffitt EA, Botsford LW, Kaplan DM, O'Farrell MR. Marine reserve networks for species that move within a home range. Ecol Appl. 2009;19:1835-47.

4. Hooker SK, Cañadas A, Hyrenbach KD, Corrigan C, Polovina JJ, Reeves RR. Making protected area networks effective for marine top predators. Endanger Species Res. 2011;13:203-18.

5. Jetz W, Carbone C, Fulford J, Brown JH. The scaling of animal space use. Science. 2004;306:266-8.

6. McNab BK. Bioenergetics and the Determination of Home Range Size. Am Nat. 1963;97:133-40.

7. Kimirei IA, Nagelkerken I, Trommelen M, Blankers P, van Hoytema N, Hoeijmakers D, et al. What Drives Ontogenetic Niche Shifts of Fishes in Coral Reef Ecosystems? Ecosystems. 2013;16:783-96.

8. Welsh JQ, Goatley CHR, Bellwood DR. The ontogeny of home ranges: Evidence from coral reef fishes. Proc R Soc B Biol Sci. 2013;280:1-7.

9. Gaines SD, Gaylord B, Gerber LR, Hastings A, Kinlan B. Connecting places: The ecological consequences of dispersal in the sea. Oceanography. 2007;20:90-9.

10. Papastamatiou YP, Meyer CG, Kosaki RK, Wallsgrove NJ, Popp BN. Movements and foraging of predators associated with mesophotic coral reefs and their potential for linking ecological habitats. Mar Ecol Prog Ser. 2015;521:155-70.

11. Froese F, Pauly D. Fishbase. www.fishbase.org. 2009.

12. Sudekum AE, Parrish JD, Radtke RL, Ralston S. Llfe history and ecology of large jacks in undisturbed, shallow, oceanic communities. Fish Bull. 1991;89.

13. Andrews AH. Giant trevally (Caranx ignobilis) of Hawaiian Islands can live 25 years. Mar Freshw Res. 2020; https://doi.org/10.1071/MF19385.

14. von Westernhagen H. Observations on the natural spawning of Alectis indicus (Ruppell) and Caranx ignobilis (Forsk.) ( Carangidae ). J Fish Biol. 1973;6:513-6.

15. Claydon J. Spawning aggregations of coral reef fishes: characteristics, hypotheses, threats and management. Oceanography and Marine Biology. 2004; 42:265-302.

16. Daly R, Filmalter JD, Daly CAK, Bennett RH, Pereira MAM, Mann BQ, et al. Acoustic telemetry reveals multi-seasonal spatiotemporal dynamics of a giant trevally Caranx ignobilis aggregation. 2019;621:185-97. 
17. Mann BQ (Ed). Southern African marine linefish species profiles. Spec. Publ. Oceanogr. Res. Insitute, Durban. 2013.

18. Glass J, Daly R, Cowley P, Post D. Spatial trophic variability of a coastal apex predator, the giant trevally Caranx ignobilis, in the western Indian Ocean. Mar Ecol Prog Ser. 2020;641:195-208.

19. Blaber SJM, Cyrus DP. The biology of Carangidae (Teleostei) in Natal estuaries. J Fish Biol. 1983;22:173-88.

20. Wetherbee BM, Holland KN, Meyer CG, Lowe CG. Use of a marine reserve in Kaneohe Bay, Hawaii by the giant trevally, Caranx ignobilis. Fish Res. 2004;67:253-63.

21. Leis JM, Hay AC, Clark DL, Chen IS, Shao KT. Behavioral ontogeny in larvae and early juveniles of the giant trevally (Caranx ignobilis) (Pisces: Carangidae). Fish Bull. 2006;104:401-14.

22. Smith GC, Parrish JD. Estuaries as Nurseries for the Jacks. Online. 2002. p. 347-59.

23. Friedlander AM. Status of Hawaii's Coastal Fisheries in the New Millennium. Proc 2001 Fish Symp. 2005;40:467-87.

24. Stoddart DR, Coe MJ, Fosberg FR. D’Arros and St Joseph, Amirante Islands. Atoll Res Bull. 1979;223:148.

25. Daly R, Stevens G, Daly CK. Rapid marine biodiversity assessment records 16 new marine fish species for Seychelles, West Indian Ocean. Mar Biodivers Rec. Marine Biodiversity Records; 2018;1-7.

26. Campbell HA, Watts ME, Dwyer RG, Franklin CE. V-Track: software for analysing and visualising animal movement from acoustic telemetry detections. Mar Freshw Res. 2012;63:815-20.

27. Udyawer V, Dwyer RG, Hoenner X, Babcock RC, Brodie S, Campbell HA, et al. A standardised framework for analysing animal detections from automated tracking arrays. Anim Biotelemetry. BioMed Central; 2018;1-14.

28. Barton K. MuMIn Multi-Model Inference. R Packag. version 1.15.6. 2016.

29. Wood SN. Generalized additive models: An introduction with R, second edition. Gen. Addit. Model. An Introd. with R, Second Ed. 2017.

30. Bates D, Mächler M, Bolker BM, Walker SC. Fitting linear mixed-effects models using Ime4. J Stat Softw. $2015 ; 67$.

31. Green AL, Maypa AP, Almany GR, Rhodes KL, Weeks R, Abesamis RA, et al. Larval dispersal and movement patterns of coral reef fishes, and implications for marine reserve network design. Biol Rev. 2015;90:1215-47.

32. Mann BQ, Cowley PD, Kyle R. Estimating the optimum size for inshore no-take areas based on movement patterns of surf-zone fishes and recommendations for rezoning of a World Heritage Site in South Africa. Ocean Coast Manag. Elsevier Ltd; 2016;125:8-19.

33. Meyer CG, Holland KN, Papastamatiou YP. Seasonal and diel movements of giant trevally Caranx ignobilis at remote Hawaiian atolls: Implications for the design of marine protected areas. Mar Ecol Prog Ser. 2007;333:13-25.

34. Lédée EJ, Heupel MR, Tobin AJ, Simpfendorfer C a. Movements and space use of giant trevally in coral reef habitats and the importance of environmental drivers. Anim Biotelemetry. 2015;3:1-14. 
35. Whitfield AK, Pattrick P. Habitat type and nursery function for coastal marine fish species, withemphasis on the Eastern Cape region, South Africa. Estuar Coast Shelf Sci. 2015;160:49-59.

36. Mumby PJ. Connectivity of reef fish between mangroves and coral reefs: Algorithms for the design of marine reserves at seascape scales. Biol Conserv. 2006;128:215-22.

37. Nagelkerken I, Grol MGG, Mumby PJ. Effects of marine reserves versus nursery habitat availability on structure of reef fish communities. PLoS One. 2012;7:1-7.

38. Sundblad G, Bergström U, Sandström A, Eklöv P. Nursery habitat availability limits adult stock sizes of predatory coastal fish. ICES J Mar Sci. 2014;71:672-80.

39. Cocheret de la Morinière E, Pollux BJA, Nagelkerken I, Hemminga MA, Huiskes AHL, Van der Velde G. Ontogenetic dietary changes of coral reef fishes in the mangrove-seagrass-reef continuum: Stable isotopes and gut-content analysis. Mar Ecol Prog Ser. 2003;246:279-89.

40. Booth DJ, Beretta GA. Influence of recruit condition on food competition and predation risk in a coral reef fish. Oecologia. 2004;140:289-94.

41. Filmalter JD, Dagorn L, Cowley PD. Spatial behaviour and site fidelity of the sicklefin lemon shark Negaprion acutidens in a remote Indian Ocean atoll. Mar Biol. 2013;160:2425-36.

42. Lea JSE, Humphries NE, von Brandis RG, Clarke CR, Sims DW. Acoustic telemetry and network analysis reveal the space use of multiple reef predators and enhance marine protected area design. Proc $R$ Soc $B$ Biol Sci. 2016;283:20160717.

43. Lea JSE, Humphries NE, Bortoluzzi J, Daly R, Brandis RG Von, Patel E, et al. At the Turn of the Tide: Space Use and Habitat Partitioning in Two Sympatric Shark Species Is Driven by Tidal Phase. 2020;7:1-13.

44. Laegdsgaard P, Johnson C. Why do juvenile fish utilise mangrove habitats? J Exp Mar Bio Ecol. 2001;257:229-53.

45. Daly R, Daly C, Gray A, Peel L, Gordon L, Lea J, et al. Investigating the efficacy of a proposed Marine Protected Area for the endangered humphead wrasse Cheilinus undulatus at a remote island group in Seychelles. Endanger Species Res. 2020;42:7-20.

46. Imansyah MJ, Jessop TS, Ciofi C, Akbar Z. Ontogenetic differences in the spatial ecology of immature Komodo dragons. J Zool. 2008;274:107-15.

47. Weng KC, Pedersen MW, Del Raye G a., Caselle JE, Gray AE. Umbrella species in marine systems: Using the endangered humphead wrasse to conserve coral reefs. Endanger Species Res. 2015;27:251-63.

48. Hughes RN, Kaiser MJ, Mackney PA, Warburton K. Optimizing foraging behaviour through learning. J Fish Biol. 1992;41:77-91.

49. Friedlander A, Filous A, Wong A, Sparks R, Ecology F, Resources N. Final report on the movements of predatory reef fishes in the Molokini Marine Life Conservation District. Mar Ecol Prog Ser. 2016;24:20212.

50. Filous A, Friedlander A, Wolfe B, Stamoulis K, Scherrer S, Wong A, et al. Movement patterns of reef predators in a small isolated marine protected area with implications for resource management. Mar Biol. Springer Berlin Heidelberg; 2017;164. 
51. Wilhelm TA, Sheppard CRC, Sheppard ALS, Gaymer CF, Parks J, Wagner D, et al. Large marine protected areas - advantages and challenges of going big. Aquat Conserv Mar Freshw Ecosyst. 2014;24:24-30.

\section{Figures}

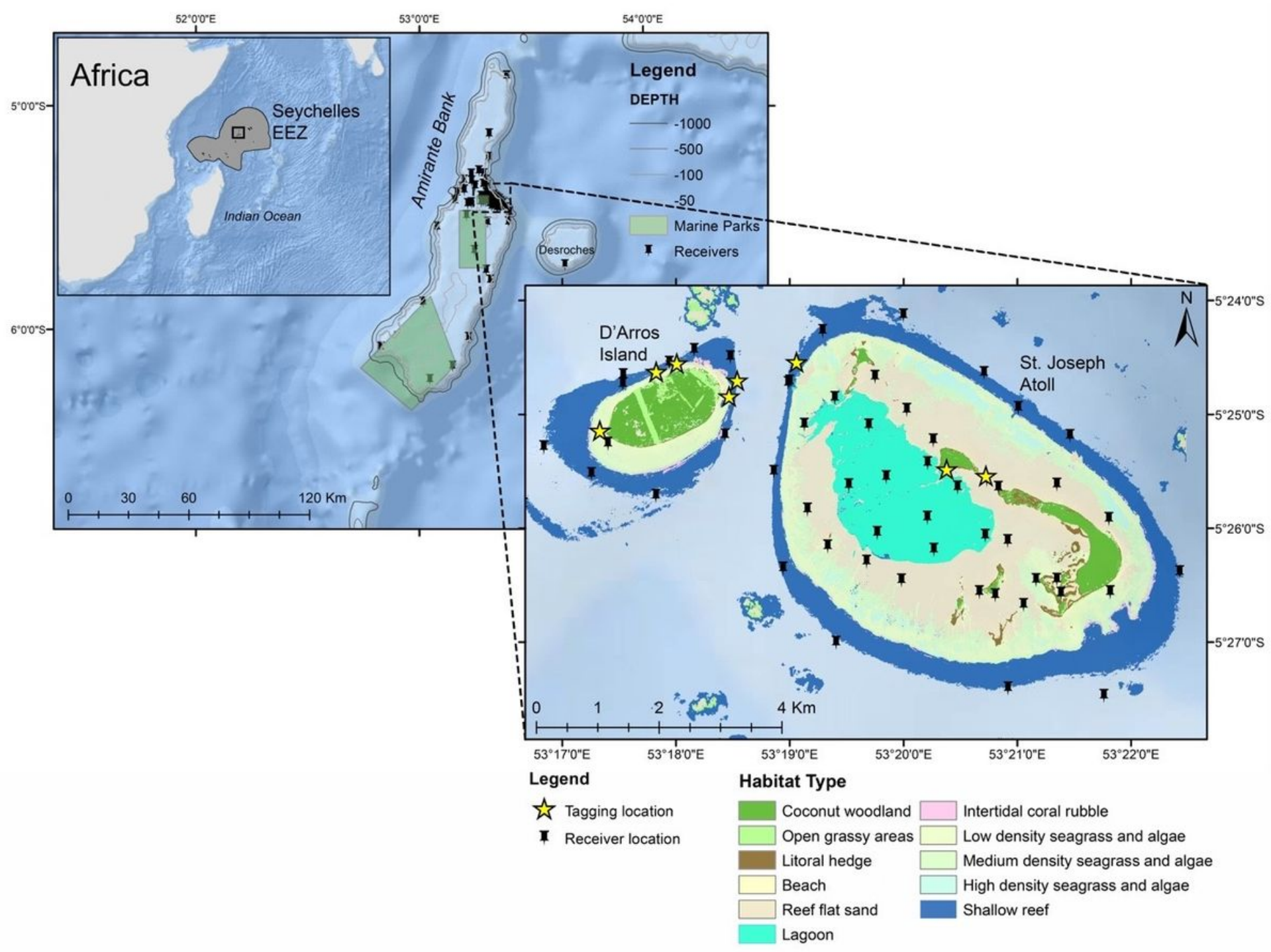

\section{Figure 1}

This study took place at D'Arros Island and St. Joseph Atoll in the Amirante Islands, Republic of Seychelles. Seventeen giant trevally were fitted with acoustic transmitters and passively monitored between 2016 and 2019 using an array of 89 acoustic receivers located throughout the Amirante Bank. Shaded blue surrounding shallow reef habitat represents deep water ( $>3 \mathrm{~m}$ deep). Note: The designations employed and the presentation of the material on this map do not imply the expression of any opinion whatsoever on the part of Research Square concerning the legal status of any country, territory, city or area or of its authorities, or concerning the delimitation of its frontiers or boundaries. This map has been provided by the authors. 


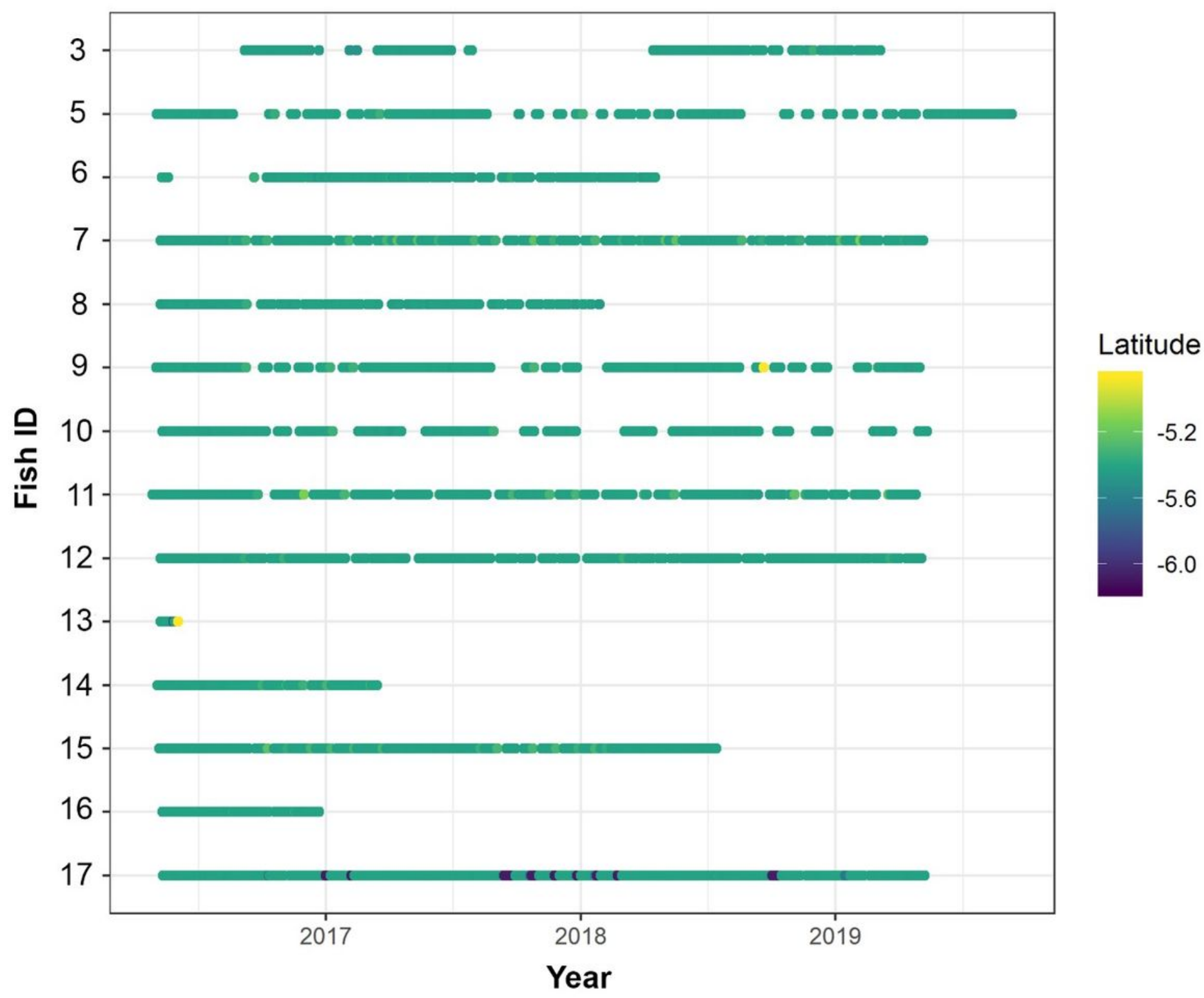

Figure 2

Summary of 14 tagged giant trevally detections across the Amirante Bank, Seychelles, acoustic receiver array between 2016 and 2019. Colour bar indicates the latitude ('South) of receivers that recorded the detection from tagged fish. 


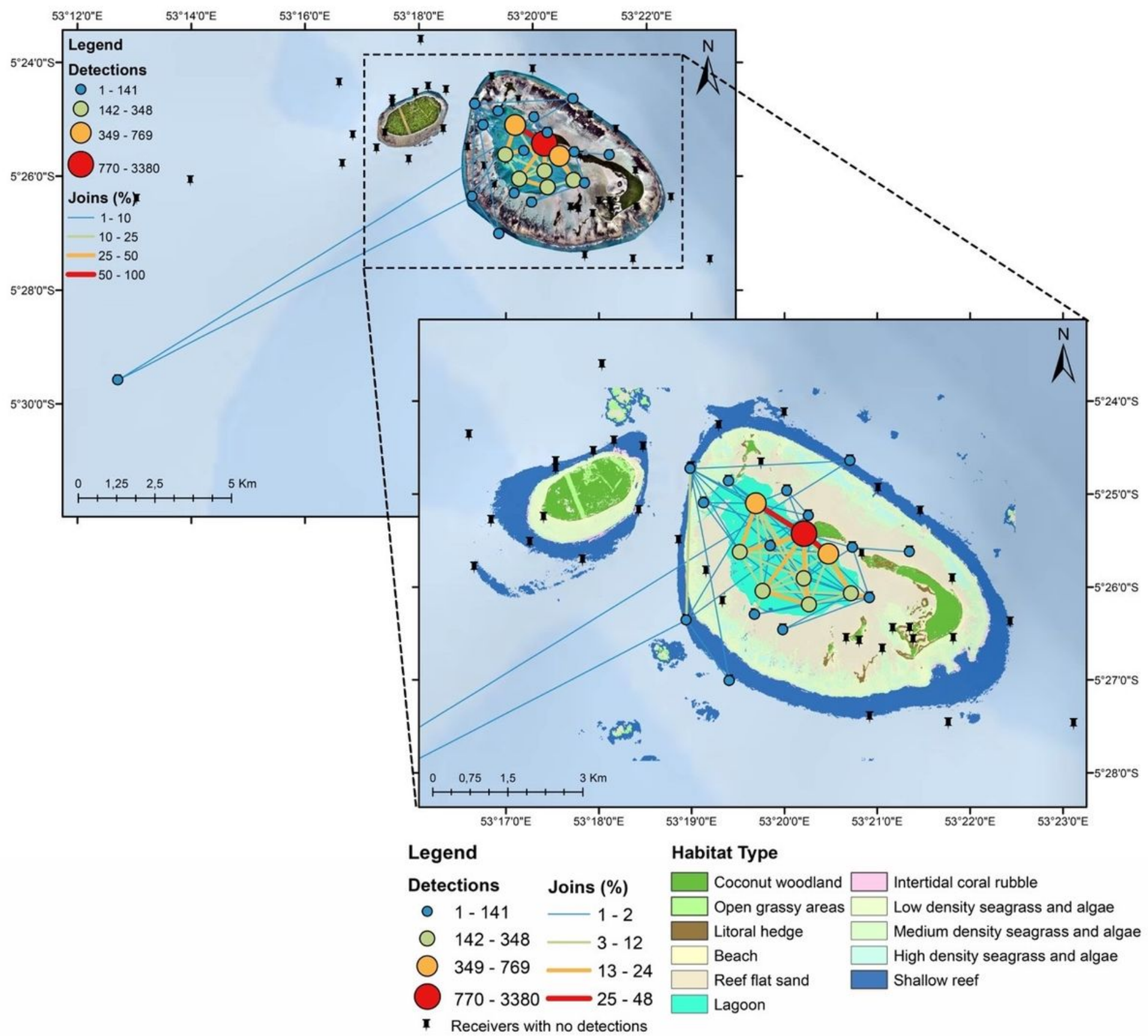

\section{Figure 3}

Network plot showing the habitat connectivity of juvenile giant trevally $(<60 \mathrm{~cm} \mathrm{FL})$ tagged at St. Joseph Atoll and monitored between 2016 and 2019. 


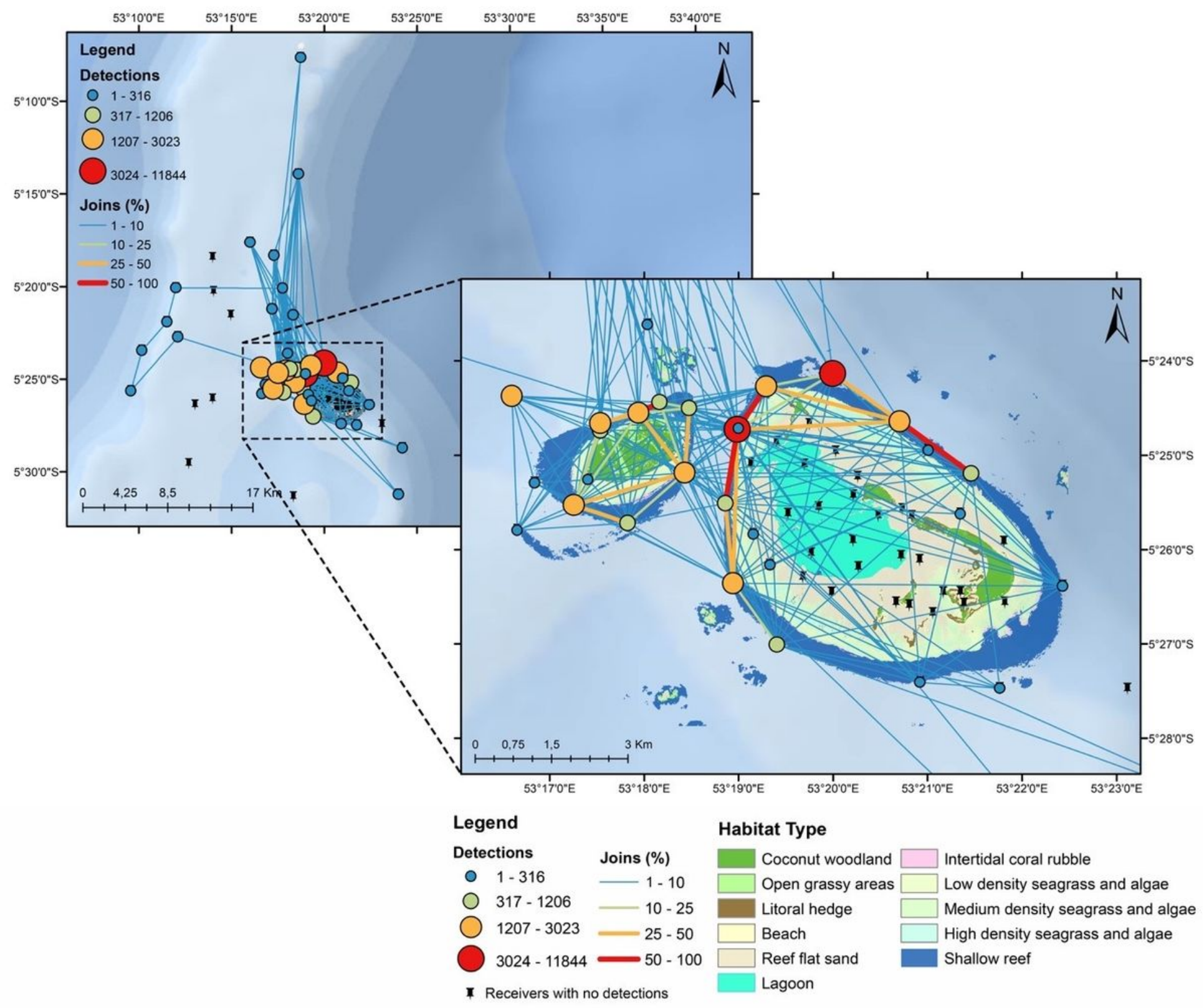

Figure 4

Network plot showing the habitat connectivity of small adult giant trevally (60 - $100 \mathrm{~cm} \mathrm{FL)} \mathrm{across} \mathrm{the}$ Amirante Bank, Seychelles, acoustic receiver array between 2016 and 2019. 


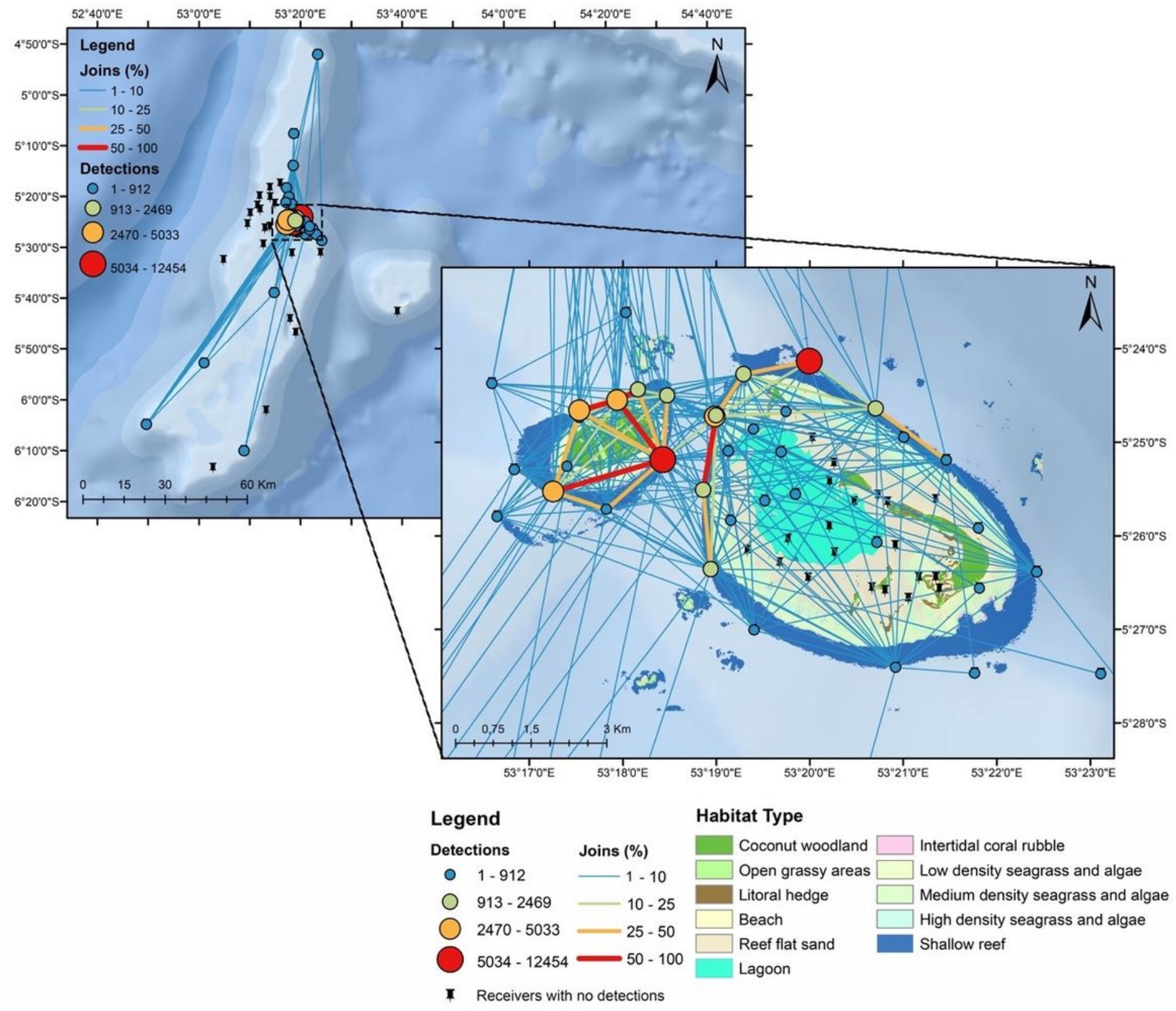

\section{Figure 5}

Network plot showing the habitat connectivity of large adult giant trevally (> $100 \mathrm{~cm} \mathrm{FL)} \mathrm{across} \mathrm{the} \mathrm{Amirante}$ Bank, Seychelles, acoustic receiver array between 2016 and 2019. 


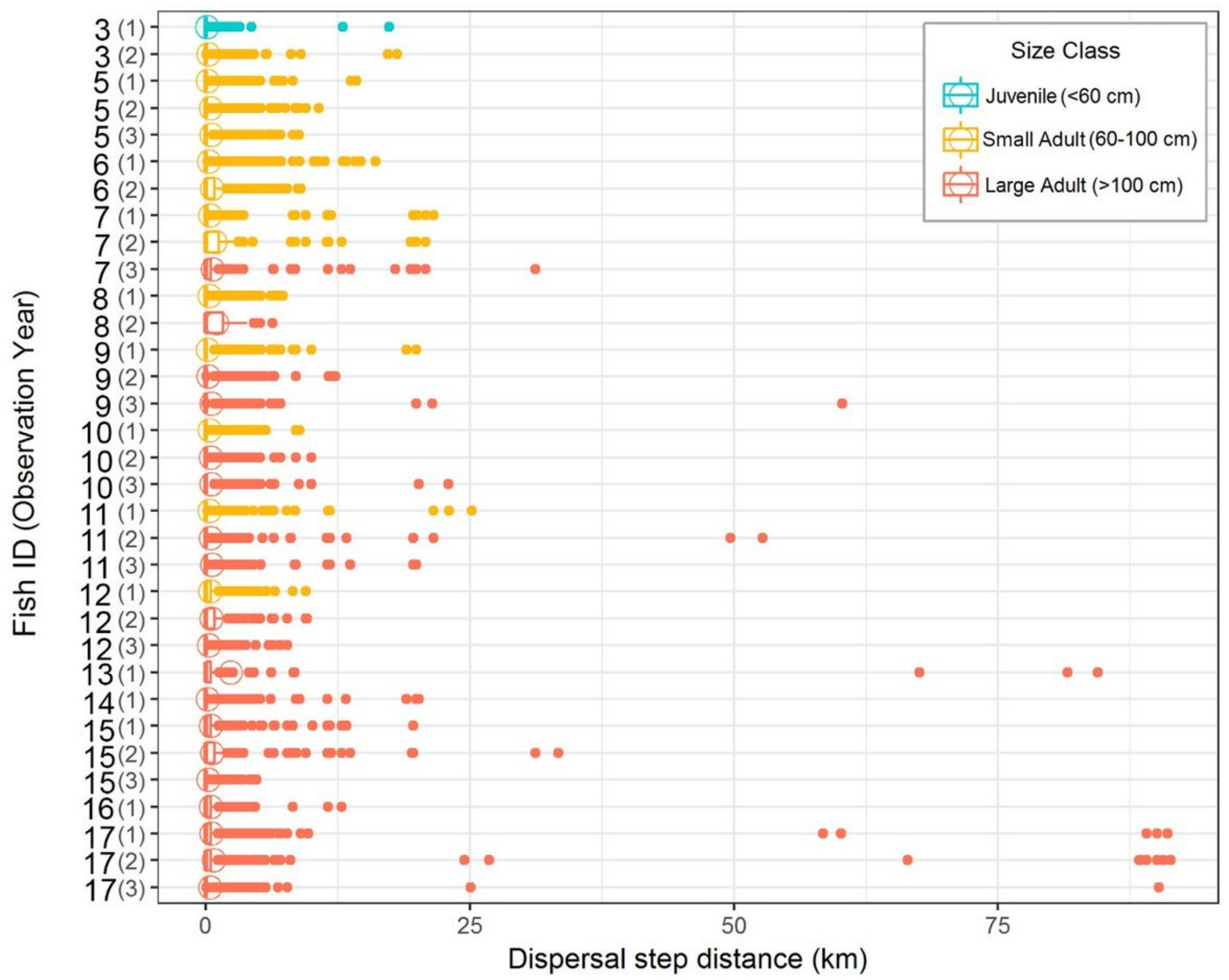

\section{Figure 6}

Annual range, mean and maximum dispersal step distances for each acoustically tagged giant trevally within the Amirante acoustic array, Seychelles. Open circles represent mean dispersal step distance, filled dots represent outliers ( $>1.5 \mathrm{x}$ interquartile range). Colour represents initial size class for each individual at capture (ID numbers in bold) and the estimated size class in subsequent years after accounting for fish growth (fork length, FL). 


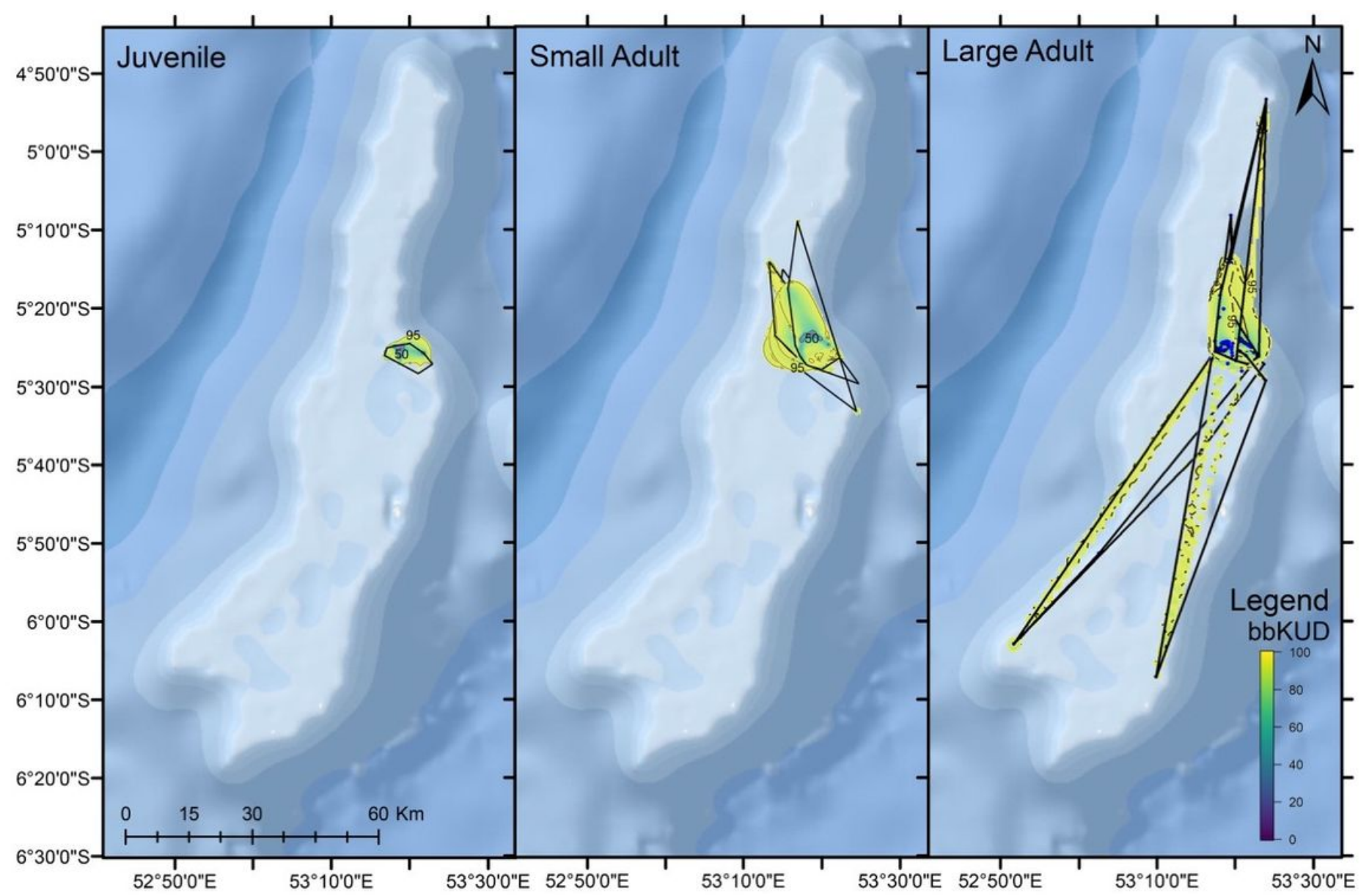

Figure 7

Individual layered home range plots for juvenile ( $<60 \mathrm{~cm} \mathrm{FL),} \mathrm{small} \mathrm{adult} \mathrm{(} 60-100 \mathrm{~cm} \mathrm{FL)}$ and large adult (>100 cm FL) giant trevally acoustically tagged in the Amirante Islands, Seychelles. The extent of the home ranges are represented by Minimum Convex Polygons (MCP; solid black lines). Brownian bridge kernel utilization density (bbKUD; see legend) contours are used to define the core home range (50\% contour) and activity space ( $95 \%$ contour) of each size class. 

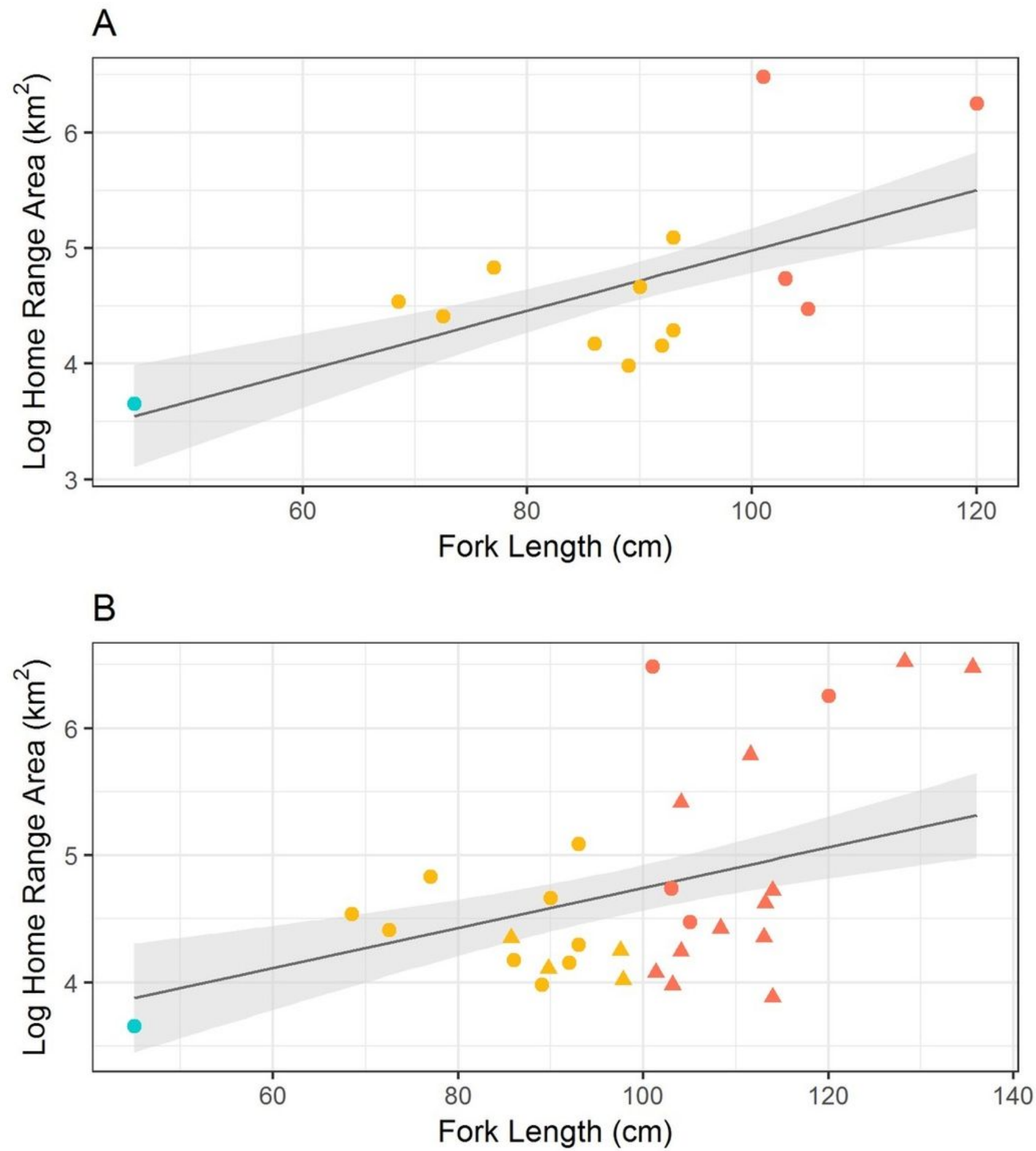

Figure 8

Results of a linear model (A) and linear mixed model (B) showing that there is a significant $(p=0.02$ and $p=$ 0.04 , respectively) relationship between fish length and log home range area (as represented by Minimum Convex Polygon area) during the first year of monitoring (A) and when fish length is estimated over time (B). Circles represent initial fork length ( $F L)$ measurements of tagged fishes and triangles represent length measurements derived from a growth curve. Blue represents juveniles $(<60 \mathrm{~cm} \mathrm{FL})$; Yellow represents small adults (60 - $100 \mathrm{~cm} \mathrm{FL);} \mathrm{Red} \mathrm{represents} \mathrm{large} \mathrm{adults} \mathrm{(>} 100 \mathrm{~cm} \mathrm{FL).}$ 

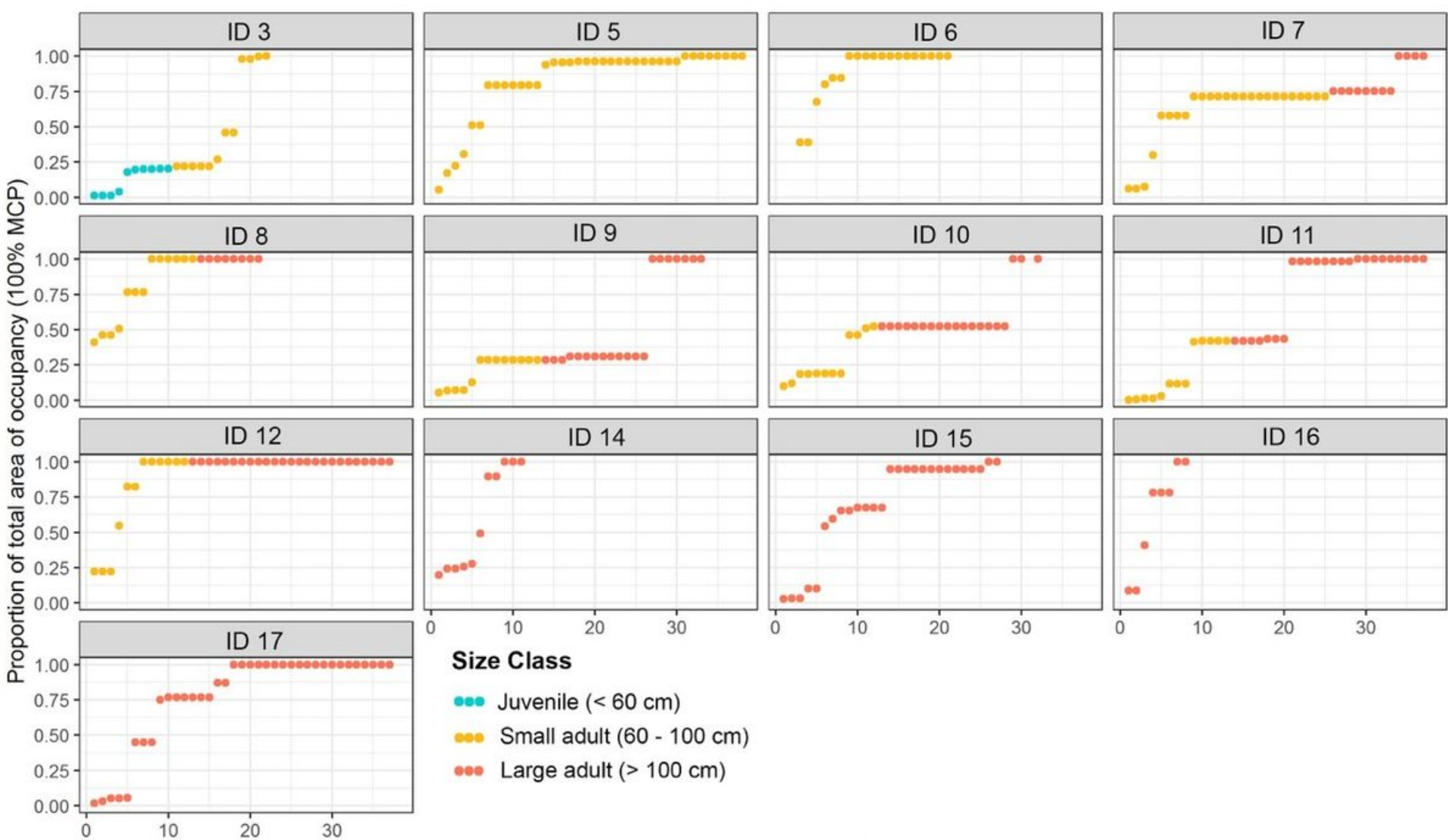

Size Class

-00 Juvenile $(<60 \mathrm{~cm})$

soo Small adult $(60-100 \mathrm{~cm})$

-eo Large adult $(>100 \mathrm{~cm})$

Time after release (months)

\section{Figure 9}

Plots showing the time (post tagging) that it took for each tagged giant trevally to reach $100 \%$ of their calculated home range (represented by Minimum Convex Polygon plots).

\section{Supplementary Files}

This is a list of supplementary files associated with this preprint. Click to download.

- Supplementarymaterial.docx 